\title{
ПРАВОВІ ЗАСАДИ КРИМІНОЛОГІЧНОГО ЗАБЕЗПЕЧЕННЯ ЕКОНОМІЧНОЇ БЕЗПЕКИ ДЕРЖАВИ
}

\author{
САЗОНОВ Василь Вікторович - кандидат юридичних наук, докторант \\ Харківського національного університету внутрішніх справ \\ DOI:10.32782/EP.2020.1.10 \\ УДК 342.336.1: 351.476.1
}

\begin{abstract}
Публікачія присвячена систематизачй чинного законодавства (сукупності законів $i$ підзаконних нормативно - правових актів), які становлять нормативно - правове поле $з$ врегулювання діяльності відповідних суб'єктів щодо забезпечення ними економічної безпеки держави.
\end{abstract}

Визначено, що нормативно-правовий напрям є одним із найбільш об'ємних сегментів у системі кримінологічного забезпечення економічної безпеки краӥни, слугує основою для ебективного ї̈ функціонування.

Наголошено на актуальності изъого напрямку кримінологічного забезпечення, що обумовлена ребормуванням та постійними законодавчими змінами у правовому регулюванні економічних процесів країни, розмитосmi та подекуди суперечливості змісту чинних нормативно - правових актів у иій сбері.

Акцентовано увагу на тому, що основу правового забезпечення протидї злочинності складають правове регулювання, правові засоби, правові явища та правовий вплив, за допомогою яких суб'єкти протидї злочинності реалізують відповідні заходи, пов'язані з протидією економічній злочинності, чим досягається нейтралізачія потениійних $і$ реальних загроз економічній безпеці Украӥни.

Зроблено висновок щодо необхідності визначення стратегічного шляху корекиіи наиіонального законодавства у сфоері кримінологічного забезпечення економічної безпеки держави, інтенсибікаиї подальших системних комплексних досліджень в означеному напрямку з метою забезпечення оптимального рівня їі стабільності, системний пошук шляхів удосконалення наявних, та за необхідності створення нових правових норм, необхідних для підвищення ефективності діяльності відповідних суб'єктів у сбері забезпечення економічної безпеки держави.

Ключові слова: правове забезпечення, нормативно - правові акти, закони, економічна безпека, загрози, протидія, кримінологічне забезпечення, економічне зростання, економічна злочинність.

\section{Постановка проблеми}

Ефективність протидії злочинності безпосередньо залежить від якості кримінологічного забезпечення цієї діяльності у вигляді створення сприятливих умов для здійснення відповідними суб’єктами (державними та недержавними органами й установами, громадськими формуваннями й окремими громадянами) впливу на злочинність із метою зниження інтенсивності процесів іiі детермінації, нейтралізації дії причин та умов злочинності для обмеження кількості злочинних проявів до певного рівня [1, с. 187].

При цьому основними напрямками, за якими повинна бути сформована система кримінологічного забезпечення економічної безпеки країни, $є$ нормативно-правовий, організаційно-управлінський, інформаційноаналітичний та науково-методичний, які, по суті, є елементами цілісної системи кримінологічного забезпечення протидії економічній злочинності. 


\section{Кримінальне право, кримінальний процес та криміналістика}

Важливість дослідження нормативно-правового напряму є беззаперечною, зважаючи на те, що він є одним із найбільш об'ємних сегментів у системі кримінологічного забезпечення економічної безпеки країни. Адже протидія злочинності, зокрема економічній, є нормативно визначеною, вона грунтується на законодавчій основі, якою керуються суб'єкти відповідної діяльності під час виконання покладених на них обов'язків.

Аналіз останніх досліджень і публікацій

У цілому стан економічної безпеки країни та питання щодо його покращення не позбавлені наукової уваги. Ці питання знайшли відображення в роботах спеціалістів різного профілю. Серед юристів цю проблематику дослідували П.П. Андрушко, О.М. Бандурка, В.С. Батиргареєва, В.О. Глушков, В.В. Голіна, I.M. Даньшин, Т.А. Денисова, О.М. Джужа, О.М. Аитвинов, О.М. Аитвак, М.І. Мельник, В. А. Мисливий, С. А. Мозоль, В.Я. Тацій, В.О. Туляков, В. В. Шаблистий, О. Ю. Шостко та інші. Серед проблем, які були ними порушені, лише фрагментарно розглядалось правове забезпечення діяльності відповідних суб'єктів у сфері забезпечення економічної безпеки, що обумовлює необхідність більш детального окреслення цього питання.

\section{Виклад основного матеріалу}

Основу правового забезпечення протидії злочинності складають правове регулювання, правові засоби, правові явища та правовий вплив, за допомогою яких суб'єкти протидії злочинності реалізують відповідні заходи. Фактично цей напрям є системою чинного законодавства, яким врегульовано діяльність суб'єктів щодо забезпечення ними економічної безпеки країни, тобто це - сукупність матеріальних і процесуальних умов, які $\epsilon$ необхідними для забезпечення ефективності діяльності суб'єктів протидії економічній злочинності.

Нормативно-правові акти, якими врегульовано процес забезпечення економічної безпеки країни, можна умовно групувати таким чином: Конституція України; міжнародні нормативно-правові акти; кодифіковані нормативно-правові акти (кодекси); Закони України; Укази Президента України,
Постанови та розпорядження Кабінету Міністрів України, нормативні акти міністерств та інших центральних органів виконавчої влади; політико-програмні документи.

На національному рівні основу законодавчого забезпечення економічної безпеки країни становить Конституиія України як базис державної політики, як основа, фундамент всієї системи законодавства, як юридична база поточного законодавства. Це трактування підкреслює властивість Основного Закону направляти в єдине русло, об'єднувати, надавати цілеспрямованості й узгодженості розвитку різних форм законодавства. Однак ця обставина не применшуе ролі Конституції України у регулюванні окремих питань, а навпаки, обгрунтовує необхідність вивчення таких норм із метою виявлення загальних правил, що є принциповими основами вже конкретнішого правового регулювання [2, с.5].

Економічна безпека держави є однією 3 фундаментальних конституційних цінностей. Прямим посиланням на це є норма, передбачена у статті 17 Конституції України, згідно з якою захист суверенітету й територіальної цілісності України, забезпечення їі економічної та інформаційної безпеки є найважливішими функціями держави, справою всього українського народу [3]. Крім того, існує ціла низка норм Конституції України, якими здійснюється опосередкований вплив на економічну безпеку держави в цілому чи окремих суб'єктів підприємницької діяльності (ст. 13, 42, 92).

Міжнародні нормативно-правові акти як джерело права. Україна розглядає інтеграцію в політичні та економічні структури Европейського Союзу (далі EC) як пріоритетний напрям своєї зовнішньої та внутрішньої політики, як європейська країна поділяє спільну історію й спільні цінності з державами - членами Европейського Союзу (EC) і налаштована підтримувати ці цінності; підтверджує, що ЕС визнає європейські прагнення України й вітає її європейський вибір, у тому числі її зобов'язання розбудовувати розвинуту та сталу демократію й ринкову економіку; визначає, що політична асоціація та економічна інтеграція України з Свропейським Союзом залежатиме від прогресу в імплементації, а також від досягнень України в забезпеченні 
поваги до спільних цінностей і прогресу в наближенні з $\mathrm{GC}$ у політичній, економічній та правовій сферах [4]. Крім того, окремі положення, які нормативно регулюють процес забезпечення економічної безпеки країни, містяться в таких міжнародно-правових актах, як Загальна декларація прав людини (1948 р.), Міжнародна конвенція щодо боротьби з підробкою грошових знаків (1929р.), Конвенція Організації Об’єднаних Націй проти транснаціональної організованої злочинності (2000 р.), Свропейська конвенція про боротьбу 3 тероризмом (1977р.), Свропейська конвенція про взаємну правову допомогу в кримінальних справах (1959 р.) та ін.

У зв'язку з тим, що економічна злочинність у нашій країні швидкими темпами набуває масштабів світового рівня та впливу, міжнародно-правові основи протидії цьому явищу мають виключно важливу роль, адже заходи, здійснювані на національному рівні окремих держав, України в тому числі, повинні бути узгоджені зі світовими орієнтирами в цьому напрямку.

Наступною групою джерел законодавчого змісту кримінологічного забезпечення економічної безпеки України є кодибіковані нормативно-правові акти, зокрема Податковий, Кримінальний, Кримінальний процесуальний, Цивільний, Митний, Бюджетний та Господарський кодекси, Кодекс України про адміністративні правопорушення та інші, окремими нормами яких прямо чи опосередковано здійснюється регулюючий вплив на сферу суспільних відносин щодо формування та реалізації державної політики у сфері забезпечення економічної безпеки.

Окрему групу становлять Закони Украӥни, якими врегульовано основні напрямки діяльності щодо кримінологічного забезпечення економічної безпеки, зокрема «Про національну безпеку України», «Про запобігання корупції», «Про запобігання та протидію легалізації (відмиванню) доходів, одержаних злочинним шляхом, фінансуванню тероризму та фінансуванню розповсюдження зброї масового знищення», «Про банки і банківську діяльність», «Про цінні папери і фондову біржу», «Про акціонерні товариства» та ін.

Наступною групою джерел є Укази Президента Украӥни, Постанови та розпоря- дження Кабінету Міністрів Украӥни, нормативні акти міністерств та інших центральних органів виконавчої влади у сфері регулювання відносин щодо кримінологічного забезпечення економічної безпеки держави, зокрема: Указ Президента України «Про систему заходів щодо усунення причин та умов, які сприяють злочинним проявам i корупції», Указ Президента України «Про рішення Ради національної безпеки і оборони України «Про нову редакцію Воєнної доктрини України», наказ Міністерства економічного розвитку і торгівлі України «Про затвердження Методичних рекомендацій щодо розрахунку рівня економічної безпеки України» та ціла низка інших нормативноправових актів, які спрямовано на врегулювання певних напрямів забезпечення економічної безпеки держави.

Окреме місце в системі законодавчого забезпечення економічної безпеки країни посідають політико-програмні документи - державні концепції, стратегії, плани розвитку, доктрини та цільові програми, що ввійшли до правової системи України, адже вони набувають юридичної форми (шляхом підписання відповідних Указів Президента України, розпоряджень Кабінету Міністрів України та ін.). Базовим документом з планування розвитку системи кримінологічного забезпечення національної економічної, серед іншого, безпеки України, є Стратегія національної безпеки України [5]. Однією з основних іï цілей визначено забезпечення якісно нової державної політики, спрямованої на ефективний захист національних інтересів в економічній, соціальній, гуманітарній та інших сферах, комплексне реформування системи забезпечення національної безпеки та створення ефективного сектору безпеки й оборони України. Окремим розділом Стратегії визначено основні заходи щодо забезпечення економічної безпеки.

Крім того, до основних програмних документів у сфері кримінологічного забезпечення економічної безпеки України слід віднести Стратегію сталого розвитку «Україна - 2020», Концепцію розвитку сектору безпеки і оборони України, Воєнну доктрину України та низку інших. Такі джерела права останнім часом займають значний сегмент у системі 


\section{Кримінальне право, кримінальний процес та криміналістика}

законодавчого забезпечення економічної безпеки, адже їх розробка та реалізація $є$ реакцією держави на ті зміни, що відбуваються, зокрема і загрози, що виникають у сфері економічної безпеки. Упровадження положень, що містяться в таких документах, здійснюється шляхом розробки нових редакцій або внесення змін до існуючих актів.

Аналізуючи стан законодавчого забезпечення діяльності з протидії економічній злочинності, науковці в принципі одностайні в тому, що суттєвим його недоліком є відсутність уніфікованого нормативно-правового акта, яким було б урегульовано державну політику у сфері протидії економічній злочинності.

Із цього приводу В. Ортинський справедливо констатує, що відсутність єдиного системоутворюючого нормативно-правового акта, який задасть темп регулювання суспільних відносин у сфері економічної безпеки, унеможливлює єдині правила для всіх учасників цих правовідносин. Приведені у відповідність до цього закону нормативно-правові акти отримали 6 обгрунтований імпульс до оновлення, а в низці випадків навіть до радикальної зміни. Факт появи такого закону запустив би процес створення нових нормативно-правових актів, які дали б змогу охопити особливо проблемні напрями економічної безпеки, що потребують додаткового регулювання [2, с. 11]. О. Гриценко вказує, що невідповідність і суперечливість нормативних актів щодо регулювання економічних процесів призвели до серйозних прорахунків, допущених на початкових етапах реформ, послаблення системи державного регулювання та контролю, що разом із недосконалістю правової бази, відсутністю дієвої державної політики у соціальній сфері, занепадом духовності й моралі суспільства стали основними чинниками, що сприяли зростанню злочинності, особливо іiі організованих форм, а також корупції. Перехід до інноваційної моделі соціально-економічного розвитку робить особливо актуальною цілеспрямовану діяльність щодо забезпечення економічної безпеки країни та їі громадян на основі єдиної державної стратегії як нормативно-правового акта. Саме такий правовий документ стане тією методологічною основою, на базі якої відбудеться правове регулювання економічних відносин у країні. Він повинен систематизувати й інтегрувати всі конкретні закони економіко-правового плану. У такому разі можна буде сподіватися на взаємодоповнюючу, синхронну дію низки законів у єдиному напрямі та з певною ефективністю. В Україні, як відомо, поки що спостерігається зворотний ефект [6, с. 281]. О. Богма вважає за необхідне розробити та затвердити на державному рівні обгрунтовану Концепцію економічної безпеки України, реалізація якої створить можливості ефективного захисту й реалізації національних економічних інтересів на основі цілеспрямованого впливу на існуючі загрози зовнішнього та внутрішнього походження [7, с.14]. 3. Гбур пропонує розробити окремий нормативноправовий акт, що закріплюватиме всі функції держави у сфері економічної безпеки, а їх виконання буде покладено на окремий орган забезпечення економічної безпеки України. При цьому дослідник вважає доречним запровадження механізмів забезпечення економічної безпеки держави Президентом та Кабінетом Міністрів України, а окрему функцію захисту, на його думку, слід покласти на Службу безпеки України й інші органи [8, с.4].

\section{Висновки та перспективи подальших досліджень}

Наголошуючи на необхідності систематизації законодавства про економічну безпеку держави, як складової національної безпеки, в науці все частіше пропонується об'єднати його в кодифікованому акті, наприклад у Кодексі про національну безпеку, в якому слід детально прописати положення, що стосуються не лише національної безпеки, а й їі окремих складових [9, с. 319]. Такий уніфікований нормативний акт, безумовно, сприятиме зміцненню цілеспрямованості, системності та конкретності законодавства у сфері економічної безпеки держави та ліквідує його надмірну розгалуженість, неузгодженість та подекуди суперечливість. Теза про перехід кількості в якість у цьому випадку є недоречною, більше того, вона свідчить про слабкість права в подоланні зазначених проблем у цілому.

Очевидно, що на сьогодні нагальними 6 необхідність визначення стратегічного шляху корекції національного законодавства у 
сфері кримінологічного забезпечення економічної безпеки та необхідність чіткої систематизації чинних нормативно-правових актів у сфері забезпечення національних економічних інтересів країни й економічної безпеки держави.

\section{Лiтература}

1.Кримінологія. Академічний курс / за заг. ред. О. М. Аитвинова. Київ : Кондор, 2018. 588 c.

2. Ортинський В. Аналіз нормативноправової основи забезпечення економічної безпеки. Вісник Національного університету «ъвівсъка політехніка». Серія: Юридичні науки. 2016. № 855. С. 4-12.

3. Конституція України : Закон України від 28.06.1996 № 254к/96-ВР // БД «Законодавство України» / ВР України. URL: http://zakon.rada.gov.ua/laws/ show/254\%D0\%BA/96-\%D0\%B2\%D1\%80 (дата звернення: 21.10.2019).

4. Про ратифікацію Угоди про асоціацію між Україною, 3 однієї сторони, та Европейським Союзом, Европейським співтовариством 3 атомної енергї і їхніми державами-членами, 3 іншої сторони : Закон України від 16.09.2014 № 1678-VII // БД «Законодавство України» / ВP України. URL: https://zakon.rada.gov.ua/laws/show/1678-18 (дата звернення: 16.10.2019).

5. Стратегія національної безпеки України : затверджена Указом Президента України від 26.05.2015 № 287/2015 // БД «Законодавство України» / ВР України. URL: http://zakon.rada.gov.ua/laws/show/287/2015/ paran14\#n14 (дата звернення: 04.09.2019).

6. Гриценко О. А., Макуха С. М. Економічна безпека держави: сутність та напрями формування : монографія. Харків : Право, 2009. 312 с.

7. Богма О. С. Аналіз рівня економічної безпеки України за основними складовими. Науковий вісник Ужгородсъкого національного університету. 2016. № 8 (1). C. 11-14.

8. Гбур 3. В. Основні функції держави у сфері забезпечення економічної безпеки. Актуальні проблеми державного управління. 2017. № 2 (52). С. 1-9.

9. Шевчук I. В. Нормативно-правове забезпечення економічної безпеки України

\section{SUMMARY}

The publication is focused on the systematization of the current legislation (a set of laws and subordinate regulatory acts), which represent the legal framework for regulating the activity of the respective entities in regard to ensure economic security of the state.

It has been determined that the regulatory area is one of the most extensive segments in the criminological system of economic security of the country. It serves as the basis for its effective functioning.

The author has emphasized the urgency of this area of criminological provision, which is conditioned by the reformation and constant legislative changes in the legal regulation of the economic processes of the country, non-specificity and sometimes contradictions in the content of existing regulatory acts in this area.

Particular attention has been paid to the fact that legal regulation, legal means, legal phenomena and legal impact constitute the basis of legal provision for combating crime. They assist the subjects of combating crime to implement appropriate measures related to combating economic crime, achieving the neutralization of potential and real threats to the economic security of Ukraine.

It has been concluded that it is necessary to determine the strategic way for correcting the national legislation in the field of criminological provision of the economic security of the state, intensification of further systematic comprehensive research in the specified area in order to ensure the optimal level of its stability, systematic search for the ways of improving the existing ones, and if necessary creating new legal norms necessary for improving the efficiency of the activity of the respective entities in the sphere of ensuring the economic security of the state.

Key words: legal provision, regulatory acts, laws, economic security, threats, counteraction, criminological provision, economic growth, economic crime.

в контексті захисту національних інтересів держави. Університетсъкі наукові записки. 2018. № 67-68. С. С. 313-321. 